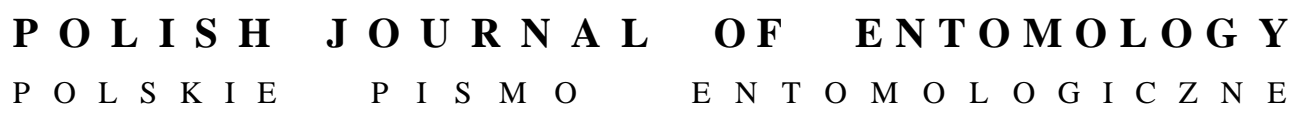

VOL. 87: 41-55

Lublin

31 March 2018

DOI: $10.2478 /$ pjen-2018-0003

\title{
New data and a checklist of Dryinidae (Hymenoptera) from Poland, and their role in controlling leafhopper and planthopper crop pests (Hemiptera: Cicadomorpha, Fulgoromorpha)
}

\author{
TOMASZ KLEJDYSZ ${ }^{1 *}$, ZDZISŁAW KLUKOWSKI ${ }^{2}$, GRZEGORZ PRUSZYŃSKI ${ }^{1}$, \\ WOJCIECH KUBASIK ${ }^{1}$
}

${ }^{1}$ Department of Entomology, Institute of Plant Protection - National Research Institute, Węgorka 20, 60-318 Poznań, Poland

${ }^{2}$ Department of Plant Protection, Wrocław University of Environmental and Life Sciences, pl. Grunwaldzki 24A, 53-363 Wrocław, Poland

\begin{abstract}
Leafhoppers and planthoppers are a large group of insects (almost 600 species in Poland) with more than 50 species living and developing on cultivated plants in Poland. They cause plant damage by sucking sap and transmitting pathogens which cause plant diseases. In integrated plant protection, non-chemical methods such as natural enemies of pests should be used for preference. This paper gives the results of preliminary research on wasps of the family Dryinidae parasitizing leafhoppers and planthoppers that are crop pests in Poland. Parasitoids were obtained by rearing larvae and catching adults in fields. Data on 11 species of Dryinidae were obtained from Poland: three of them were not previously known from this country. A checklist of Dryinidae species known from Poland is given: it shows the species of Dryinidae parasitizing leafhoppers and planthoppers living on crops, and their role in reducing populations of these pests.
\end{abstract}

KEY WORDS: Chrysidoidea, parasitoids, Cicadellidae, Delphacidae, natural enemies.

\section{INTRODUCTION}

Dryinidae are wasps (Hymenoptera) belonging to the suborder Apocrita and the superfamily Chrysidoidea, which includes, besides Dryinidae, seven other families

\footnotetext{
* Corresponding author: t.klejdysz@iorpib.poznan.pl
} 
(BROTHERS \& FinNAMORE 1993). Four of them (Bethylidae, Chrysididae, Embolemidae and Sclerogibbidae) are represented in the European fauna (OLMI \& Mitroiu 2013).

Wasps of the superfamily Chrysidoidea are characterized by a small body size. Many species have marked sexual dimorphism and some are wingless. In the imago stage they may be active predators but some also feed on pollen. The larvae are parasitoids of various groups of insects or nest kleptoparasites of other Hymenoptera. It has been estimated that there are around 16000 species in the superfamily Chrysidoidea (BROTHERS \& FINNAMORE 1993), approximately 1840 of which are Dryinidae (OLMI \& XU 2015). To date, 21 species of Dryinidae were known in Poland; three further, newly recorded ones are presented in this paper. Beyond these, another 10 or so additional species can be expected (CELARY 2004). Most existing data come from before World War II and refer only to one locality on the western border of the country - Bielinek (German name - "Bellinchen an der Oder") (HAUPT 1932, 1937, 1938, 1941).

Dryinidae are easily distinguishable from other species of the superfamily by the presence of 10 segmented antennae placed low above the clypeus. The characteristic feature of females in the family Dryinidae (with the exception of the subfamilies Aphelopinae and Erwiniinae) is the "chela", a kind of pincers formed by the modified fifth segment of the protarsus, and an enlarged claw for gripping the potential host or prey.

Different species of Dryinidae specialize in parasitizing hoppers of the suborders Fulgoromorpha and Cicadomorpha, formerly classified as belonging to one paraphyletic taxon - Auchenorrhyncha. Females of Dryinidae paralyse their prey with a sting and lay one, or rarely two or more eggs inside their bodies. In Europe, most Dryinidae larvae are ectoparasitoids; only younger larvae of Aphelopus spp. live inside the host. Feeding larvae are attached to the host body (usually between sclerites of the abdomen or thorax) remaining within a characteristic capsule or cyst called a "thylacium" (Fig. 1). On completion of feeding, they leave the host (which always dies) and spin a silk cocoon in which they pupate. Adult males generally do not feed, although they can suck honeydew excreted by leafhoppers; they die shortly after mating. Females, on the other hand, are active predators (with the exception of the subfamily Aphelopinae, whose front legs have no chela) and hunt for the same hoppers in which their larvae develop. They can also feed on honeydew (OLMI 1999).

\section{MATERIAL AND METHODS}

This study was conducted in 2011-2013. Parasitized leafhoppers and planthoppers collected in the field were reared in laboratory conditions. Imaginal specimens of Dryinidae were also caught using Barber pitfall traps and light lures. Moreover, samples from yellow 
water traps and sweep nets were taken from the beginning of April to the middle of July in 2006-2009, mainly from the margins of fields of winter oilseed rape and maize, or winter wheat.

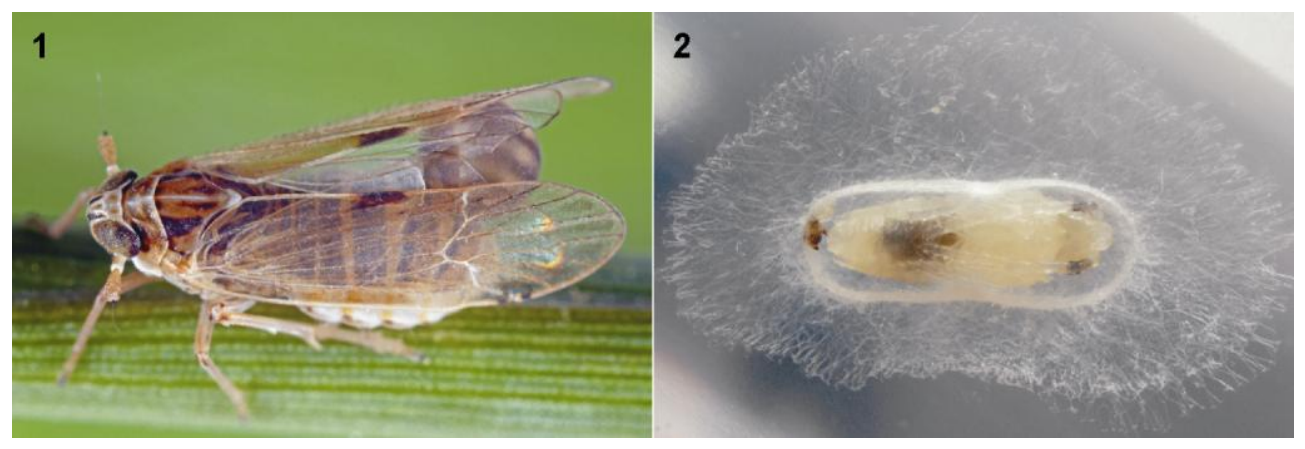

Figs 1, 2. 1 - Laodelphax striatellus (FALLÉN, 1826) parasited by a Dryinidae wasp; 2 - Haplogonatopus oratorius (WESTWOOD, 1833) pupa seen through the transparent wall of the container used for breeding.

The study focused on the most common species of leafhoppers and planthoppers occurring on crops in Poland: Macrosteles laevis (RIBAUT, 1927), Psammotettix alienus (DAHLBOM, 1850), Javesella pellucida (FABRICIUS, 1794), Laodelphax striatellus (FALLÉN, 1826), Eupteryx atropunctata (GoEZE, 1778), Empoasca pteridis (DAHLBOM, 1850) and Hardya tenuis (GERMAR, 1821) as hosts of Dryinidae. Leafhoppers and planthoppers with visible symptoms of parasitization were collected on the most important agricultural crops cultivated in Poland and in the nearest vicinity (field margins, meadows, fallow land, etc.). Parasitized hoppers for rearing were caught in western Poland at Winna Góra, Borowo, Iłówiec and Poznań. Parasitized hoppers (Fig. 1) were swept from plants and taken to the laboratory in polypropylene vials in a portable refrigerator. In the laboratory parasitized leafhoppers and planthoppers were placed in transparent polypropylene tubes (diameter 1.5 $\mathrm{cm}$; length $10 \mathrm{~cm}$ ). Both ends were plugged with lignin. A leaf of a plant growing in a pot was inserted into the tube. We used cockspur grass (Echinochloa crus-galli (L.) BEAUV.) and young barley plants (Hordeum vulgare L.). Cultures were checked every 1-2 days. Data on the emergence of the mature dryinid larva from the host's body, cocooning (Fig. 2), emergence of dryinid imagines and other relevant information were noted. Reared adults of Dryinidae were identified by using available keys (OLmI 1984, 1994, 1999, OLMI \& XU 2015). The nomenclature was adopted after OLMI (1999). If not stated otherwise, all specimens were reared, collected and identified by the first author. The identifications were 
verified by Massimo OLMI. Species marked with an asterisk were not previously known from Poland. The collected and reared specimens are in the collections of the first two authors.

The localities are given with an accuracy of $10 \mathrm{~km}$ using UTM (Universal Transverse Mercator system) coordinates and the name of the nearest village.

The level of parasitization in the field was determined as the percentage of insects with visible symptoms of parasitism of all caught individuals of the species. Leafhoppers and planthoppers were caught at the same time and in the same environment as the parasitized insects for rearing using entomological sweep nets. The insects were caught during 20 to 50 beats of the sweep net, then transferred to a fine textile bag and killed in ethyl acetate vapour. Leafhoppers and planthoppers with visible symptoms of parasitization and those without them were identified and counted under a stereomicroscope in the laboratory.

\section{RESULTS}

\section{Species data}

During the present research, 11 species of Dryinidae were collected or reared. Three of them were not previously reported from Poland. In this study, 148 rearings of preimaginal stages of Dryinidae were conducted, but only 20 yielded imagines of Dryinidae. One species of Dryinidae was obtained only by rearing, five species were collected in the study area, and the other five were obtained both by rearing and catching. The results of rearings and catches are presented below.

\section{Anteon ephippiger (DALMAN, 1818)}

- Ołdrzychowice Kłodzkie [UTM: XR28]: (alt. 420 m), 17 VIII 2007, 1우, in sweep net, fallow land close to Salix viminalis L. plantation and forest. Z. KLUKOWSKI leg., det. et coll.

- Winna Góra [UTM: XT68]: 07 VII 2013, larva on female of Macrosteles laevis, larva in cocoon since 9 VII 2013, ex cult. 1 9 , 20 VII 2013, crop of spring barley; 7 VII 2013,

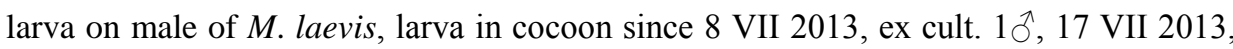
crop of spring barley; 09 VIII 2012, older larva on thorax of female of M. laevis, larva in cocoon since 16 VIII 2012, ex cult. 19, 31 VIII 2012, margins and the immediate surroundings of fields; 14 VIII 2012, older larva on thorax of female of M. laevis, larva in cocoon since 18 VIII 2012, ex cult. 19, 31 VIII 2012, margins and the immediate surroundings of fields; 14 VIII 2012, older larva on thorax of female of M. laevis, larva in cocoon since 20 VIII 2012, ex cult. 1ㅇ, 31 VIII 2012, margins and the immediate surroundings of fields. 
This species has a wide distribution range, from Japan to western Europe (OLMI \& XU 2015). Previously Anteon ephippiger was noted in Poland by GARBARCZYK (1987) from villages around Warsaw. It parasitizes species of the family Cicadellidae, genera: Deltocephalus BURMEISTER, 1838, Opsius FIEBER, 1866, Psammotettix HAUPT, 1929, Macrosteles FIEBER, 1866, Macropsis LEWIS, 1936 and Mocydia EDWARDS, 1922 (GUGLIELMINO \& OLMI 1997, 2006, 2007, GUGLIELMINO et al. 2013).

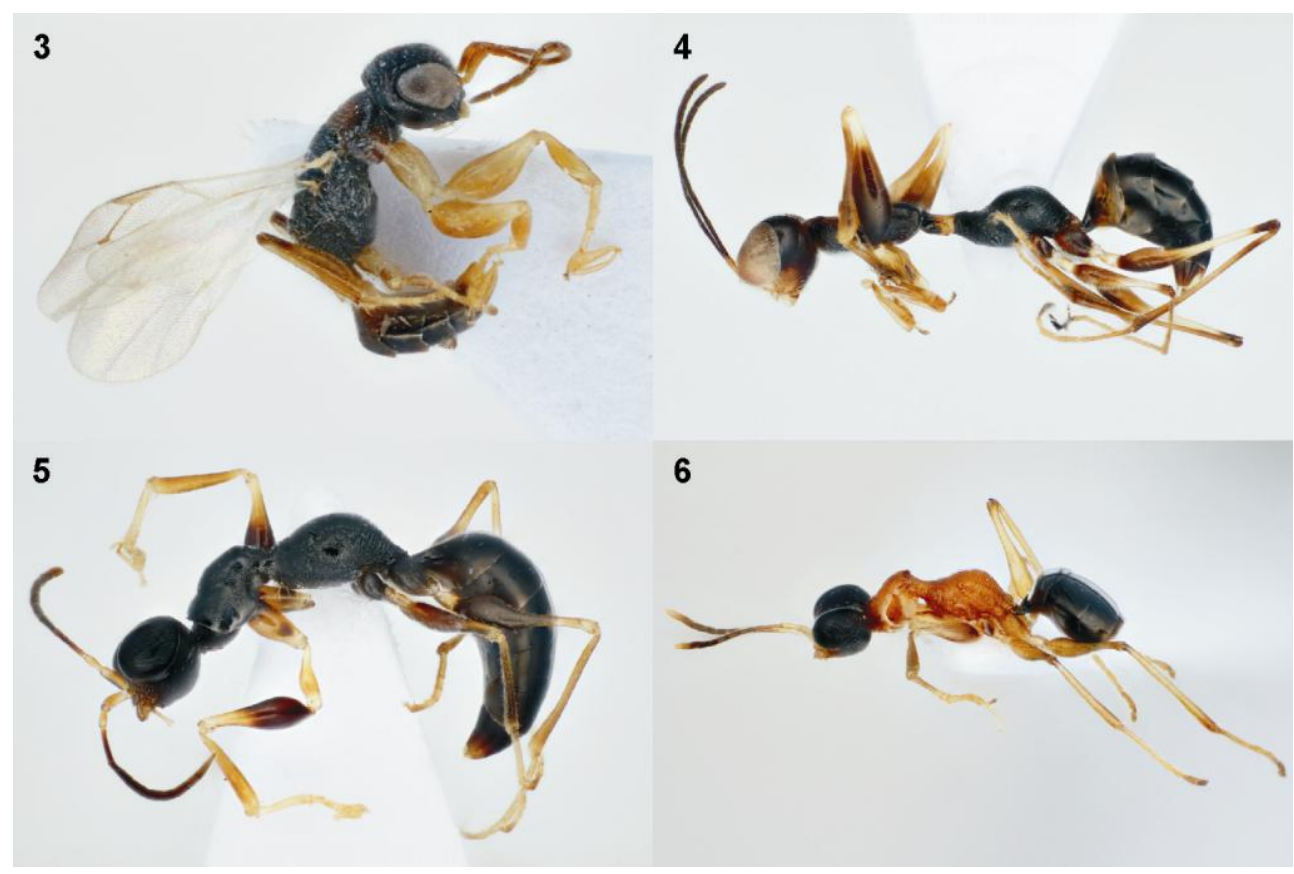

Figs 3-6. Most interesting of the species recorded: 3 - Anteon fulviventre (HALIDAY, 1828), female; 4 - Gonatopus lunatus KLUG, 1810, female; 5 - Gonatopus solidus (HAUPT, 1938), female; 6 - Haplogonatopus oratorius (WESTWOOD, 1833), female.

\section{Anteon fulviventre (HALIDAY, 1828) * (Fig. 3)}

- Wrocław-Swojec [UTM: XS46]: 14 VIII 2007, 19, from a yellow water trap, maize plot. Z. KLUKOWSKI leg., det. et coll.

- Przeworno [UTM: XS51]: 8 VIII 2006, 19, from a yellow water trap, fallow land close to a field from which winter oilseed rape had been harvested. Z. KLUKOWSKI leg., det. et coll. 
Anteon fulviventre occurs throughout Europe and in parts of Asia (the Far East of Russia - OlMI \& XU 2015), and North Africa (PEETERS et al. 2004). It is a parasitoid of species of the subfamily Deltocephalinae (Cicadellidae), genera: Mocydia, Macrosteles and Opsius (Guglielmino \& Olmi 1997, 2006, 2007, Guglielmino et al. 2013). New to the Polish fauna.

\section{Gonatopus bicolor (HALIDAY, 1828)}

- Rogalin [UTM: XT38]: 29 IV 2012, larva on abdomen of Delphacidae nymph, larva in cocoon since 08 V 2012, ex cult. 1 9 , 08 V 2012, meadow.

- Wrocław-Swojec [UTM: XS56]: 4 IX 2008, 1 9 , from a yellow water trap, field margin close to forest margin. Z. KLUKOWSKI leg., det. et coll.

Palearctic species, occurring from Western Europe to the Far East in Asia (OLMI \& XU 2015, PEETERS et al. 2004). It develops on many species of planthoppers of the family Delphacidae, genera: Criomorphus CURTIS, 1833, Delphacinus FIEBER, 1866, Dicranotropis FIEBER, 1866, Ditropis KIRSCHBAUM, 1868, Gravesteiniella WAGNER, 1963, Hyledelphax VILBASTE, 1968, Javesella FenNAH, 1963, Laodelphax FENNAH, 1963, Megadelphax WAGNER, 1963, Ribautodelphax WAGNER, 1963, Stiroma FIEBER, 1866 and Unkanodes FenNAH, 1956 (GUGLIELMINo \& Olmi 1997, 2006, 2007, GUGLIELMINo et al. 2013). Species known from Poland: Świnoujście (OLMI \& XU 2015) and from villages in the Warsaw area (GARBARCZYK 1987).

\section{Gonatopus clavipes (THUNBERG, 1827)}

- Winna Góra [UTM: XT68]: 07 VI 2011, larva on abdomen of female of Errastunus ocellaris (FALLÉN, 1806), larva in cocoon since 13 VI 2011, ex cult. 1우, 20 VI 2011, margins and the immediate surroundings of fields; 23 VIII 2012, older larva on abdomen of male of Psammotettix alienus, larva in cocoon since 27 VIII 2012, ex cult. 1 9,26 IX 2012, margins and the immediate surroundings of fields.

- Stara Olszyna [UTM: BD90]: 27 VII 2016, 1 9 , in a sweep net on crop of spring barley.

- Wrocław-Swojec [UTM: XS56]: 14 VI 2009, 19, from a yellow water trap, field margin close to forest margin. Z. KLUKOWSKI leg., det. et coll.

This a species with a wide range, occurring from the Canary Islands through the Middle East to Japan. In the north it is present from Ireland to Siberia (OLMI \& XU 2015). Gonatopus clavipes is known to parasitize about 50 species of the family Cicadellidae, genera: Adarrus RIBAUT, 1947, Araldus RIBAUT, 1946, Arthaldeus RIBAUT, 1946, Cicadula ZetTerstedt, 1840, Deltocephalus, Elymana DeLong, 1936, Errastunus RiBaUt, 1947, Euscelidius RIBAUT, 1942, Euscelis BrULLÉ, 1832, Exitianus BALL, 1929, Goldeus RIBAUT, 
1946, Hardya EDWARDS, 1922, Jassargus LATREILle, 1825, Latalus DeLong \& SleEsman, 1929, Paramesus FIEBER, 1866, Psammotettix, Recilia EdWARds, 1922, Rhopalopyx RIBAUT, 1939, Scaphoideus UhLER, 1889, Sorhoanus RIBAUT, 1946, Streptanus RiBAUT, 1942, Thamnotettix ZetTERSTEDT, 1840 and Verdanus OMAN, 1949 (Guglielmino \& Olmi 1997, 2006, 2007, Guglielmino et al. 2013). Species already known from Poland (GUGLIELMINO \& OLMI 1997).

\section{Gonatopus distinguendus KIEFFER, 1905}

- Kórnik [UTM: XT49]: 05 VIII 2012, 19, collected in a sweep net, roadside.

- Ratno Górne-Gajów [UTM: WR99]: 9 VI 2009, 2 q, from a yellow water trap, fallow land close to a field from which winter oilseed rape had been harvested. Z. KLUKOwSKI leg., det. et coll.

This species occurs in Europe and Asia as far as eastern Russia. Rarely captured (PEETERS et al. 2004). In Poland known from Bielinek (HAUPT 1938). It is a parasitoid of leafhoppers of the subfamily Deltocephalinae (Cicadellidae), genera: Adarrus, Araldus, Condylotes Emeljanov, 1959, Diplocolenus Latreille, 1825, Mocuellus Ribaut, 1946, Neoaliturus Distant, 1918, Psammotettix and Rhopalopyx (GUGliELmino \& Olmi 1997, 2006, 2007, GUGLIELMINO et al. 2013).

\section{Gonatopus formicarius LJUNGH, 1810}

- Wrocław-Wojnów [UTM: XS56]: 4 VII 2007, 1, from a yellow water trap, fallow land close to a forest. Z. KLUKOWSKI leg., det. et coll.

Species with a Eurasian distribution (OLMI \& XU 2015). It develops on many species of the subfamily Deltocephalinae (Cicadellidae), genera: Adarrus, Deltocephalus, Diplocolenus, Doratura SAHLberg J.R., 1871, Jassargus, Psammotettix and Verdanus (GugliELMino \& OLMI 1997, 2006, 2007, GUGLIELMiNo et al. 2013).

\section{Gonatopus lunatus KLUG, 1810 * (Fig. 4)}

- Szymany [UTM: DE92]: 20 VII 2012, 1 9 , in a Barber pitfall trap, meadow, leg. K. KOMOSIŃSKI.

- Czarnów [UTM: VU82]: Ujście Warty [Warta Mouth] National Park, 17 VI 2012, 1우, in a sweep net, meadow, leg. T. RUTKOwSKI.

- Stara Olszyna [UTM: BD90]: 27 VII 2016, 19 , in a sweep net in crop of spring barley.

- Wrocław-Wojnów [UTM: XS56]: 4 VII 2007, 1, from a yellow water trap, fallow land close to a forest. Z. KLUKOWSKI leg., det. et coll. 
This is a species with a wide distribution covering most of Europe and Palaearctic Asia (PeEters et al. 2004, OlMI \& XU 2015). New to the Polish fauna. It develops on species of the subfamily Deltocephalinae (Cicadellidae), genera: Adarrus, Arthaldeus, Artianus RiBaUt, 1942, Circulifer ZachVATKIN, 1935, Deltocephalus, Doratura, Enantiocephalus HAUPT, 1926, Errastunus, Euscelis, Euscelidius, Jassargus, Macrosteles, Maiestas Distant, 1917, Neoaliturus, Opsius, Paramesus, Psammotettix, Recilia, Scaphoideus and young nymphs of Ommatidiotus inconspicuus STÅL, 1863 (Fulgoromorpha: Caliscelidae) (Guglielmino \& Olmi 1997, 2006, 2007, GuGLIELMiNO et al. 2013).

\section{Gonatopus solidus (HAUPT, 1938) (Fig. 5)}

- Przewóz [UTM: VT90]: 11 VII-03 VIII 2011, 19, in a Barber pitfall trap, crops of rye.

- Poznań, Dębiec [UTM: XU21]: 26 VII 2012, older larva on abdomen of female of Ribautodelphax sp. larva in cocoon since 28 VII 2012, ex cult., 10, 13 VIII 2012.

Species described from Bielinek (HAUPT 1938). In Europe it occurs from France to Poland. In the east it is known from the eastern borders of Russia (OLMI \& XU 2015). A parasite of Laodelphax striatella (FALLÉn, 1826), Megadelphax sp. and Muirodelphax aubei (PERRIS, 1857) (GUGLIELMINO et al. 2013).

$$
\text { Haplogonatopus oratorius (WESTWOOD, 1833) * (Fig. 6) }
$$

- Winna Góra [UTM: XT68]: 08 VIII 2012, older larva on abdomen of female of Laodelphax striatellus, larva in cocoon since 08 VIII 2012, ex cult., 1 + 16 VIII 2012; 08 VIII 2012, 2q; 09 VIII 2012, older larva on abdomen of nymph of Delphacidae, larva in cocoon since 13 VIII 2012, ex cult., 1+, 24 VIII 2012; 09 VIII 2012, older larva on abdomen of nymph of Delphacidae, larva in cocoon since 13 VIII 2012, ex cult., $1 \delta^{\lambda}$, 24 VIII 2012; 09 VIII 2012, older larva on abdomen of nymph of Delphacidae, larva in cocoon since 13 VIII 2012, ex cult., 1ㅇ, 24 VIII 2012; 14 VIII 2012, older larva on

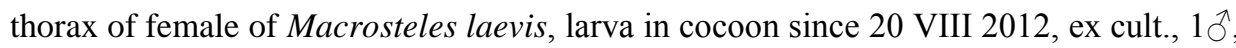
31 VIII 2012; 14 VIII 2012, older larva on thorax of male of nymph of Delphacidae,

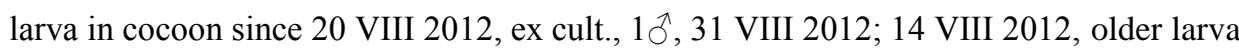
on abdomen of female of Laodelphax striatellus, larva in cocoon since 20 VIII 2012, ex

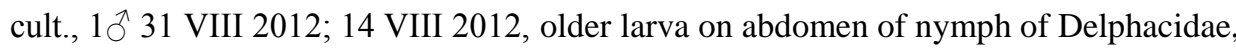
larva in cocoon since 20 VIII 2012, ex cult., 1 đ 31 VIII 2012; 23 VIII 2012, older larva on abdomen of nymph of Delphacidae, larva in cocoon since $20 \mathrm{VIII} 2012$, ex cult., $1 \hat{O}^{\lambda}$, 31 VIII 2012; 31 VIII 2012, older larva on abdomen of nymph of Delphacidae, larva in cocoon since 03 IX 2012, ex cult., 1ㅇ, 18 IX 2012. 
Parasitized planthoppers from which specimens of Haplogonatopus oratorius were collected on the margins and immediate surroundings of crop fields. The larvae of Dryinidae on parasitized hoppers were already quite large and left the host within a few days.

H. oratorius is known from many countries in Europe, the Middle East and the Eastern Palaearctic (OLMI \& XU 2015). It has also been recorded in North Africa (OlmI \& MitroIU 2013). This is the first find of this species in Poland. It develops on planthoppers of the family Delphacidae, genera: Laodelphax, Megadelphax and others (GUGLIELMINO \& OLMI 1997, 2006, 2007, Guglielmino et al. 2013). The development of Haplogonatopus oratorius on Macrosteles laevis (species of family Cicadellidae) has not been recorded in the literature before.

This record is probably an exception because Haplogonatopus oratorius is a Delphacidae parasite (GugLIELMINo et al. 2013). This can be explained by the unstable ecological conditions in the vicinity of fields, which could induce a parasitoid to settle on an accidental host (M. laevis). Similar examples of atypical parasitoid-host relations for Dryinidae species have been reported by other researchers, e.g. Gonatopus lunatus (Deltocephalinae parasitoid) may also develop in young larvae of Ommatidiotus inconspicuus (Caliscelidae) (OLMI \& XU 2015).

\section{Lonchodryinus ruficornis (DALMAN, 1818)}

- Winna Góra [UTM: XT68]: 14 VIII 2012, older larva on the abdomen of male Errastunus ocellaris, larva in cocoon since 16 VIII 2012, ex. cult. $1 \delta^{\uparrow} 18$ IX 2012, margins and immediate surroundings of crops (var. frontalis DALMAN).

- Wołowe Lasy [UTM: WU88]: 1 ㅇ 22 V 2005, brachypterous form.

- Wrocław-Wojnów [UTM: XS56]: 4 VIII 2007, 1우, in a sweep net, fallow land close to a forest. Z. KLUKOwSKI leg., det. et coll.

Palearctic species. Probably common in most European (Peeters et al. 2004) and Asian countries (OLMI \& XU 2015). Already known from Poland (Haupt 1941, Wiśniowski 2016). L. ruficornis can develop on a wide range of hosts leafhoppers of the subfamily Deltocephalinae (Cicadellidae): Arthaldeus, Conosanus OSBORN et BALL, 1902, Elymana, Errastunus, Euscelis, Jassargus, Macrosteles, Mocydia, Psammotettix and Streptanus (Guglielmino \& OlMi 1997, 2006, 2007, GUGLIELMINO et al. 2013, OLMI 1999). 


\section{Mystrophorus formicaeformis RUTHE, 1859}

- Rogalin [UTM: XT38]: 19 IV 2014, 19 captured on grassy vegetation in a meadow.

This species is present in Europe and western Asia (PEETERS et al. 2004). Hosts are representatives of the subfamily Deltocephalinae (Cicadellidae): Deltocephalus, Diplocolenus, Doratura, Psammotettix and Verdanus (GugliELmino \& OlMI 1997, 2006, 2007, GUGLIELMINO et al. 2013).

\section{Parasitization level}

In order to determine the parasitization level, 94 catches of leafhoppers and planthoppers were made yielding 3762 individuals. Table 1 shows the parasitization level of the leafhoppers and planthoppers depending on different habitats.

Table 1. Percentage of parasitism of leafhoppers and planthoppers in different habitats.

\begin{tabular}{clcc}
\hline No. & \multicolumn{1}{c}{ Family and species } & Meadow/field margins & Crops \\
\hline & Cicadellidae & & \\
1. & Empoasca pteridis (DAHLBOM, 1850) & $0-31$ & $0-21$ \\
2. & Errastunus ocellaris (FALLÉN, 1806) & $15-77$ & $<1$ \\
3. & Eupteryx atropunctata (GOEZE, 1778) & $1-16$ & 0 \\
4. & Hardya tenuis (GERMAR, 1821) & 0 & 0 \\
5. & Macrosteles laevis (RIBAUT, 1927) & $3-11$ & $0-6$ \\
6. & Psammotettix alienus (DAHLBOM, 1850) & $12-26$ & $<1$ \\
& Delphacidae & $11-18$ & $0-4$ \\
7. & Javesella pellucid (FABRICIUS, 1794) & $13-23$ & $0-6$ \\
8. & Laodelphax striatellus (FALLÉN, 1826) & \\
\hline
\end{tabular}

\section{DISCUSSION}

Knowledge of the hymenopteran family Dryinidae occurring in Poland is extremely poor in comparison with global data (OLMI 1984). Also, compared with most of the neighbouring countries, very little is known about this group of insects in Poland (MACEK 2007). Most of the historical data about Dryinidae found in Poland come from HAUPT's research $(1932,1937,1938,1941)$, conducted before World War II in the vicinity of Bielinek, a small town by the River Oder in north-western Poland (then in Germany). There have been very few reports on the Polish Dryinidae since then. A little new information can be found in the catalogue of GUGLIELMINO \& OLMI (1997) with supplements 
Table 2. Checklist of Dryinidae known from Poland. Sources: 1 - HAUPT (1916), 2 - HAUPT (1932), 3 - HAUPT (1937), 4 - HAUPT (1938), 5 - HAUPT (1941), 6 - FIORI (1984), 7 - GARBARCZYK (1984), 8 - OLMI (1984), 9 - GARBARCZYK (1987), 10 - Guglielmino \& OLMi (1997), 11 - OLMI (1999), 12 - WiŚNIOWSKI (2016), 13 - current paper.

\begin{tabular}{|c|c|c|c|}
\hline No. & Species & Locality & Source \\
\hline \multirow[t]{2}{*}{1.} & Anteon ephippiger (DALMAN, 1818) & Bielinek & 5,6 \\
\hline & & near Warsaw & 7 \\
\hline \multirow[t]{2}{*}{2.} & A. еxiguит (HAUPT, 1941) & Bielinek & 5 \\
\hline & & no detailed data & 11 \\
\hline 3. & A. fulviventre (HALIDAY, 1828) & Bielinek & 5 \\
\hline 4. & A. flavicorne (DALMAN, 1818) & Bielinek & 5 \\
\hline 5. & A. gaullei KIEFFER, 1905 & Bielinek & 5 \\
\hline \multirow[t]{3}{*}{6.} & A. pubicorne (DALMAN, 1818) & Bielinek & 5 \\
\hline & & Tatras - Kościelisko Valley & 8 \\
\hline & & $\begin{array}{l}\text { Ojców National Park - Skała } \\
\text { Krzyżowa }\end{array}$ & 12 \\
\hline 7. & A. scapulare (HALIDAY, 1837) & Bielinek & 5 \\
\hline 8. & Aphelopus atratus (DALMAN, 1823) & no detailed data & 11 \\
\hline \multirow[t]{2}{*}{9.} & A. camus RICHARDS, 1939 & Bielinek & 8 \\
\hline & & no detailed data & 11 \\
\hline 10. & A. serratus RICHARDS, 1939 & no detailed data & 11 \\
\hline 11. & Dryinus collaris (LINNAEUS, 1767) & Bielinek & 2 \\
\hline \multirow[t]{2}{*}{12.} & D. tarraconensis MARSHALL, 1868 & Bielinek & 4 \\
\hline & & Bielinek & 5 \\
\hline \multirow[t]{2}{*}{13.} & Gonatopus bicolor (HALIDAY, 1828) & Świnoujście & 1,6 \\
\hline & & near Warsaw & 9 \\
\hline \multirow[t]{2}{*}{14.} & G. clavipes (THUNBERG, 1827) & no detailed data & 10 \\
\hline & & Śląsk (Silesia) & 8 \\
\hline 15. & G. distinguendus KIEFFER, 1905 & Bielinek & 4 \\
\hline 16. & G. formicarius LJUNGH, 1810 & no detailed data & 11 \\
\hline 17. & G. lunatus KLUG, 1810 & $\begin{array}{l}\text { Szymany, Czarnów, Stara Olszyna, } \\
\text { Wrocław - Wojnów }\end{array}$ & 13 \\
\hline 18. & G. pedestris DALMAN, 1818 & no detailed data & 11 \\
\hline 19. & G. solidus (HAUPT, 1938) & Bielinek & 4 \\
\hline 20. & $\begin{array}{l}\text { G. spectrum (SNELLEN VAN VOLLENHOVEN, } \\
\text { 1874) }\end{array}$ & Bielinek & 11 \\
\hline 21. & G. striatus Kieffer, 1905 & no detailed data & 11 \\
\hline 22. & Haplogonatopus oratorius (WESTWOOD, 1833) & Winna Góra & 13 \\
\hline \multirow[t]{2}{*}{23.} & Lonchodryinus ruficornis (DALMAN, 1818) & Bielinek & 5 \\
\hline & & Ojców National Park - Bukówki & 12 \\
\hline 24. & Mystrophorus formicaeformis RUTHE, 1859 & Bielinek & 4 \\
\hline
\end{tabular}


(Guglielmino \& Olmi 2006, 2007, Guglielmino et al. 2013). In the Polish literature there are only a few mentions of Dryinidae. Most of these insects were caught using nonselective methods, and their identification was typically restricted to family level (KęDZIORA \& KARG 2010). WiŚNIOWSKI (2016) reported two species (Table 2) from the Ojców National Park.

Among the Polish studies on the ecology and the role of Dryinidae in agriculture, a paper by GARBARCZYK (1987) is noteworthy, because the author identified two species of Dryinidae occurring on rye - Gonatopus bicolor and Anteon ephippiger, which parasitize planthoppers and leafhoppers respectively. GROMADZKA (1970) investigated Dryinidae parasitizing Empoasca pteridis, a pest of potato crops in Poland. Their identification, however, was again limited to family level. That author reported the level of parasitism of E. pteridis on potato crops to be from 7 to $57 \%$.

The limited knowledge of the Dryinidae of Poland is due mainly to the lack of specialists investigating this group of insects (CELARY 2004). Identification of species can pose a lot of problems because of their small body size, the need to perform microscopic analysis, and the frequent changes in nomenclature (for example: the genus Gonatopus LJUNGH, 1810 has 40 synonyms) (OLMI \& Mitroiu 2013).

Our research revealed that Dryinidae parasitize almost all the important species of leafhoppers and planthoppers found in agricultural communities in western Poland. The degree of parasitism differs in terms of both the species and habitat where the parasites are found. Leafhoppers and planthoppers were more likely to be infested by Dryinidae in field margins and meadows adjacent to fields than on the fields themselves. While this is probably due to the reduced mobility of Dryinidae females, which are often wingless and thus migrate slowly deep into the field, it could also be an effect of the insecticides applied there (although farmers were not interviewed on this matter). Farmlands are highly dynamic systems because of the annual changes in their exploitation. For this reason, stable ecosystems cannot establish themselves there, and their colonization by wingless Dryinidae is difficult. Parasitized leafhoppers and planthoppers captured in cultivated fields will probably have been infested earlier in a non-farming environment.

Among the leafhoppers commonly found in cultivated fields, only specimens of Hardya tenuis were not parasitized by Dryinidae. H. tenuis has recently become very common in west-central Poland (KLEJDYSZ 2013, KLEJDYSZ 2017), and it is possible that the relevant parasitoids need time to adapt to this species. This species, unlike most other Deltocephalinae crop pests, overwinters as an imago on winter cereals. In spring they migrate to the grass on which they develop, and in autumn return to the winter crops. It is therefore possible that the different phenology of $H$. tenuis may be the reason why Dryinidae are not attracted to this host. 
Despite the relatively low level of parasitization of leafhoppers and planthoppers in crop fields by Dryinidae, the importance of these parasites may be greater than it seems. These wasps not only limit the number of pests by their parasitism, but they also hunt them, so that their activity is greatly enhanced. The majority of Deltocephalinae occurring on crops overwinter as eggs in plant tissues on balks and in meadows. There they develop into the first generation of parasites. Afterwards, they migrate to crops and give rise to the second and further generations of pests. Dryinidae play the most important role in reducing the population of these pests, specifically on balks, in meadows and the surroundings of fields, where the level of parasitism is much higher than on the fields themselves. The elimination of females from the first generation of leafhoppers and planthoppers has a significant impact on the abundance of the next generation of pests. It is important, therefore, to preserve the diversity of habitats in the agricultural landscape.

In a study carried out at Turew near Poznań (Poland), KARG \& BALAZY (2009) reported a significantly greater abundance of insects, entomopathogenic fungi and other natural enemies of pests in fields surrounded by uncultivated areas, meadows, etc. This observation corresponds to that of BOLLER et al. (2004), who emphasized the role of field margins as an important component of agricultural communities and one of the most important tools for modelling biological diversity, especially natural enemies of plant pests. Also, MARSHALL \& MOONEN (2002) showed that field margins are very important habitats for insects, especially for natural enemies of pests. Compared with the countries of western Europe, Poland has a well-preserved and high biodiversity. It is important to sustain and increase this biodiversity within the framework of integrated plant protection programmes.

The present study suggests that Anteon ephippiger and Haplogonatopus oratorius may have an important role in reducing the populations of leafhoppers and planthoppers most frequently recorded in western Poland. The former parasitizes the most important pest of cereal crops - Macrosteles laevis, while the latter reduces the number of delphacid planthoppers, which are also common on many types of crops.

\section{ACKNOWLEDGEMENTS}

We are grateful to Prof. Massimo OLMI at the Tropical Entomology Research Centre (Viterbo, Italy) for verifying the species identifications and his valuable comments on the manuscript during its preparation.

The project was funded by a grant from the National Science Centre on the basis of decision number DEC-2011/01/N/NZ9/04271 


\section{REFERENCES}

Boller E.F., HÄNi F., Poehling H-M. 2004. Ecological infrastructures. Ideabook on functional biodiversity at the farm level. Swiss Centre for Agricultural Extension and Rural Development (LBL), Eschikon, Switzerland.

Brothers D.J., Finnamore A.T. 1993. Superfamily Vespoidea [in:] H. Goulet, J.T. Huber (eds.). Hymenoptera of the world: an identification guide to families. Research Branch, Agriculture Canada, Ottawa, 161-278.

Celary W. 2004. Dryinidae. [in:] W. BogdanowicZ, E Chudzicka., I. Pilipiuk, E. SKibińsKa (eds.). Fauna of Poland - characteristics and checklist of species. Vol. 1. Muzeum i Instytut Zoologii PAN Warszawa, 338-339. (in Polish)

GARBARCZYK M. 1987. Leafhoppers (Homoptera, Auchenorrhyncha) and their parasitoids on rye crops with different surroundings. Polish Ecological Studies 13: 195-213.

GROMADZKA J. 1970. Observations on the biology and occurence of leafhoppers Eupteryx atropunctata (GoEZE) and Empoasca pteridis (DHLB.) (Homoptera, Typhlocybinae) on potatoes. Polskie Pismo Entomologiczne 40(4): 830-840. (in Polish)

Guglielmino A., Olmi M. 1997. A host-parasite catalog of world Dryinidae (Hymenoptera: Chrysidoidea). Contributions on Entomology, International 2(2): 165-298.

Guglielmino A., Olmi M. 2006. A host-parasite catalog of world Dryinidae (Hymenoptera: Chrysidoidea). First supplement. Zootaxa 1139(39): 35-62.

Guglielmino A., Olmi M. 2007. A host-parasite catalog of world Dryinidae (Hymenoptera: Chrysidoidea). Second supplement. Bollettino di Zoologia Agraria e di Bachicoltura, Ser. II 39(2): 121-129.

Guglielmino A., Olmi M., BÜCKLE C., 2013. An updated host-parasite catalogue of world Dryinidae (Hymenoptera: Chrysidoidea). Zootaxa 3740(1): 1-113.

Haupt H. 1932. Die Mundteile der Dryinidae (Hym.). Zoologischer Anzeiger 99(1-2): 1-18.

HAUPT H. 1937. Ein neuer Dryinus (Hym.). Zeitschrift für Naturwissenschaften 91: 69-77.

HAUPT H. 1938. Zur Kenntnis der Dryinidae I (Hymenoptera-Sphecoidea). Zeitschrift für Naturwissenschaften 92: 13-35.

HAUPT H. 1941. Zur Kenntnis der Dryinidae II (Hymenoptera-Sphecoidea). Zeitschrift für Naturwissenschaften 95: 27-67.

KARG J., BAŁAZY S. 2009. Effect of landscape structure on the occurrence of agrophagous pests and their antagonists. Progress in Plant Protection 49(3): 1015-1034. (in Polish)

KęDZiora A., Karg J. 2010. Threats and protection of biodiversity. Nauka 4: 107-114. (in Polish)

KLEJDYSZ T. 2013. Leafhoppers and planthoppers (Hemiptera: Cicadomorpha \& Fulgoromorpha) as part of the harmful entomofauna on major crops in Poland. PhD thesis, Institute of Plant Protection - National Research Institute, Poznań. (in Polish)

KLEJDYSZ T. 2017. Hardya tenuis (GERMAR, 1821) - a new threat to crops of winter cereals in Poland? DGaaE-Nachrichten 31(1): 23-24. 
MACEK J. 2007. Chrysidoidea: Dryinidae (lapkovití) and Embolemidae (vejřenkovití). [in:] P. Bogusch, J. StRaKa, P. KMENT (eds.). Annotated checklist of the Aculeata (Hymenoptera) of the Czech Republic and Slovakia. Acta Entomologica Musei Nationalis Pragae. Supplementum 11, $65-84$.

Marshall E.J.P., Moonen A.C. 2002. Field margins in northern Europe: their functions and interactions with agriculture. Ecosystems and Environment 89(1-2): 5-21.

Olmi M. 1984. A revision of the Dryinidae (Hymenoptera). Memoirs of the American Entomological Institute 37: 1-1913.

Olmi M. 1994. Fauna Entomologica Scandinavica 30. The Dryinidae and Embolemidae (Hymenoptera: Chrysidoidea) of Fennoscandia and Denmark. E.J. Brill, Leiden.

Olmi M. 1999. Fauna of Italy XXXVII. Hymenoptera: Dryinidae - Embolemidae. Edizioni Calderini, Bologna. (in Italian)

Olmi M., MitroiU M.-D. 2013. Fauna Europaea: Dryinidae. [in:] Fauna Europaea version 2.6.2. Internet: http://www.faunaeur.org.

Olmi M., Xu Z. 2015. Dryinidae of the Eastern Palaearctic region (Hymenoptera: Chrysidoidea). Zootaxa 3996(1): 1-253.

Peeters T.M.J., van Achterberg C., Heitmans W.R.B., Klein W.F., Lefeber V., van Loon A.J., MAB A.A. 2004. Dutch Fauna 6. The aculeate wasps and ants of the Netherlands (Hymenoptera: Aculeata). Nationaal Natuurhistorisch Museum Naturalis Leiden, KNNV Uitgeverij Utrecht \& European Invertebrate Survey - Nederland, Leiden.

Wiśniowski B. 2016. Catalogue of Hymenoptera (Arthropoda: Insecta) of the Ojców National Park. Prądnik. Prace i Materiały Muzeum im. Prof. Władysława Szafera 26: 95-146. (in Polish)

Received: 8 August 2017

Accepted: 19 September 2017 